e-ISSN: 2721-3013, p-ISSN: 2721-3005

DOI: https://doi.org/10.38035/jafm.v1i1

Received: 20 February 2020, Revised: 27 Ferbruary, Publish: 3 March 2020

https://creativecommons.org/licenses/by/4.0/



\title{
Comparative Analysis of Energy Productivity Used to Manage Waste with Comparison of Pelet Outputs in Electricity in STT- PLN Jakarta
}

\author{
Pawenary ${ }^{*}$, Supriadi Legino ${ }^{2}$, Mega Cintya ${ }^{3}$ \\ ${ }^{1)}$ Sekolah Tinggi Teknik PLN, pawenary@itpln.ac.id \\ ${ }^{2}$ Sekolah Tinggi Teknik PLN, supriadi@itpln.ac.id \\ ${ }^{3)}$ Sekolah Tinggi Teknik PLN, megacintya28797@gmail.com \\ *Corresponding Author: Pawenary ${ }^{1}$
}

\begin{abstract}
In STT-PLN environment each day has the potential to produce $875 \mathrm{~kg}$ of waste per day, based on this value it can be used as a waste pellet of $43.5 \mathrm{~kg}$ per day. STT-PLN Jakarta Electricity Jakarta launched the Local Waste Management Method (TOSS) with this method, STT-PLN is able to manage its own waste which is expected to be a solution for the utilization of waste into fuel. The machines used are hammer mill and chopper machine with $22 \mathrm{~kW}$ of power and operated for 3 hours, worth Rp.193,680.96 per day. Pellet production is used as fuel which can be distributed to PLTSa, Biomass Power Plants and pellet stoves. Based on the results of the calculation of the economic analysis obtained is NVP of IDR 454,007,469.00, IRR 26,855\% and PBP 4,84 years, STT-PLN Jakarta Electricity is feasible to be continued.
\end{abstract}

Keywords: TOSS, Pellet, Electricity, PLTSa

\section{INTRODUCTION}

The problem of waste has always been a serious problem in all regions of Indonesia. Not only Indonesia, but also throughout the world. Increasing population growth is directly proportional to the production of waste generated every day. Waste which is identical with unpleasant odor can also disturb human health. will certainly bring negative impacts on the environment. For example floods, disease outbreaks and cause air pollution. From the various negative impacts of waste, it turns out there are positive sides. Waste is a potential that can be converted into electrical energy.

The energy sector in Indonesia is currently trying to develop New and Renewable Energy (EBT) not only as an alternative to fossil fuels but is a buffer of the national energy supply with a portion of New and Renewable Energy (EBT) of 23\% in 2025 of the total electricity supply which exists. (source: ebtke.esdm.go.id).

Based on the above background, STT-PLN (State College of Engineering-State 
Electricity Company) Jakarta as an academic party launched the Local Waste Management Program (TOSS) managed by the Electricity Electricity (LK). This is done as an effort to deal with the waste problem by stopping shipments of waste to the final processing site (TPA), by managing waste in STT-PLN Jakarta. But in this research by implementing the Local Waste Management Site (TOSS) is expected to overcome the problem of waste by converting waste into fuel. The fuel is known as garbage pellets. To convert waste into pellets, there is a process of illuminator after which it is filtered and chopped using a chopper machine and then printed with a pellet printing machine, the machine used requires electrical energy from an electric energy source.

With this, the researcher will examine whether the waste pellet produced is greater than the price of the use of electrical energy to rotate the electric motor on a chopper and printer, or vice versa.

The purpose of this study was to determine how much electrical energy is needed to be able to run an electric motor on a chopper and a pellet printer. Determine whether the waste pellets produced in rupiah is greater than the cost incurred to produce waste pellets or vice versa. Knowing whether this pellet is feasible in terms of productivity, profitability with the analysis of cash flow on People's Electricity at STT-PLN Jakarta.

The problem in this study is to analyze the comparison of the electrical energy productivity used to manage waste by comparing the output value of pellets on Electricity Electricity in STT-PLN Jakarta knowing productivity, profitability with cash flow analysis throughout the process of making fuel with waste raw material until it becomes a pellet and study its eligibility.

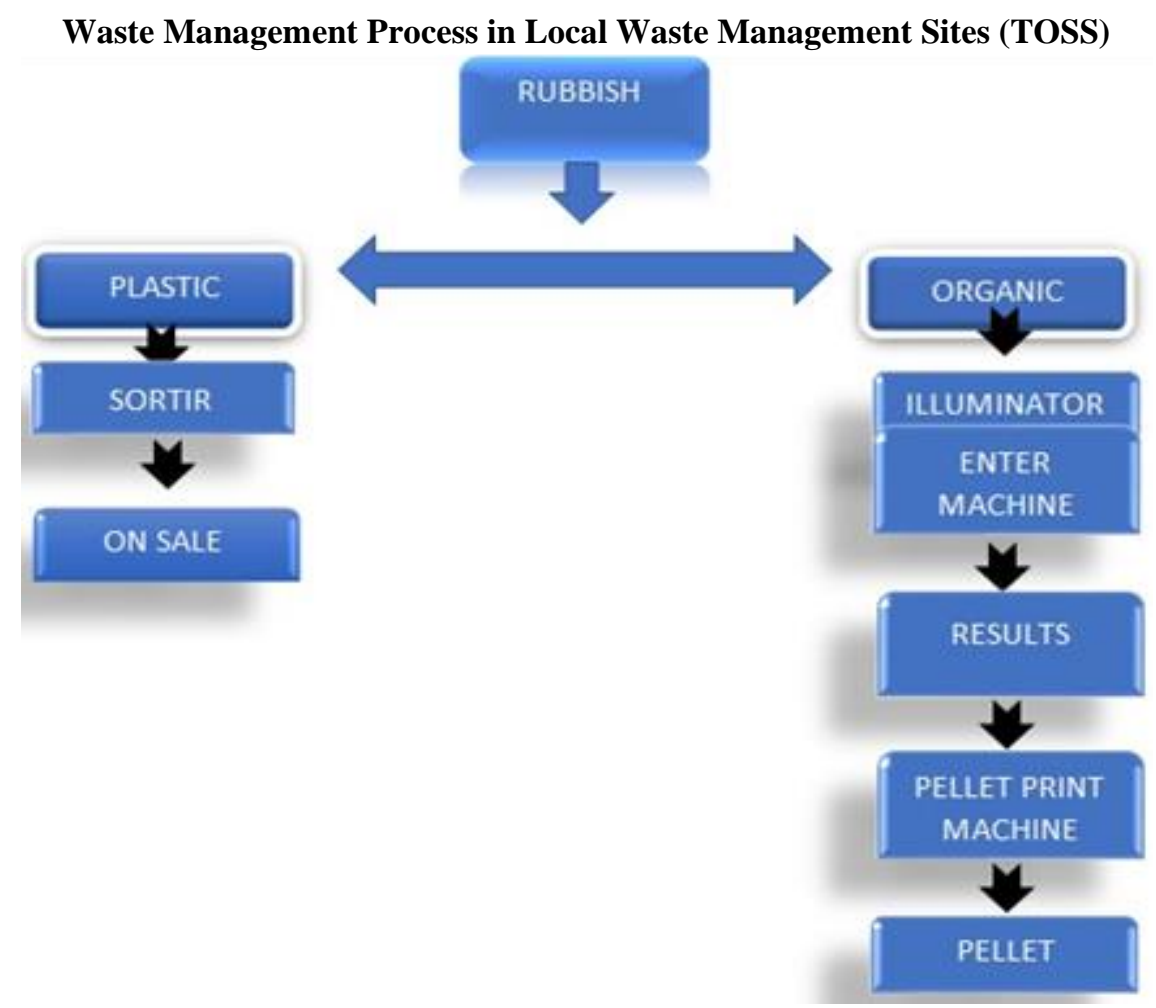

Figurer 1. Process Diagram with the TOSS Method 


\section{RESEARCH METHODS}

The research design used is the observation method. Where researchers make direct observations of the object under study to observe the actual situation on the ground. The analysis technique used in this study is a descriptive statistical analysis technique. Where in this study conducted an assessment of the data in the Electricity STT-PLN Jakarta. The data that has been obtained is then processed to obtain the desired index. The processed data will later be described during the data analysis process. Data in the form of the results of the process of the arrival of waste until it becomes pellet output and know productivity, profitability with cash flow analysis throughout the process of making fuel with waste raw materials to become pellets and feasibility studies. The research framework is used as shown in the figure below.

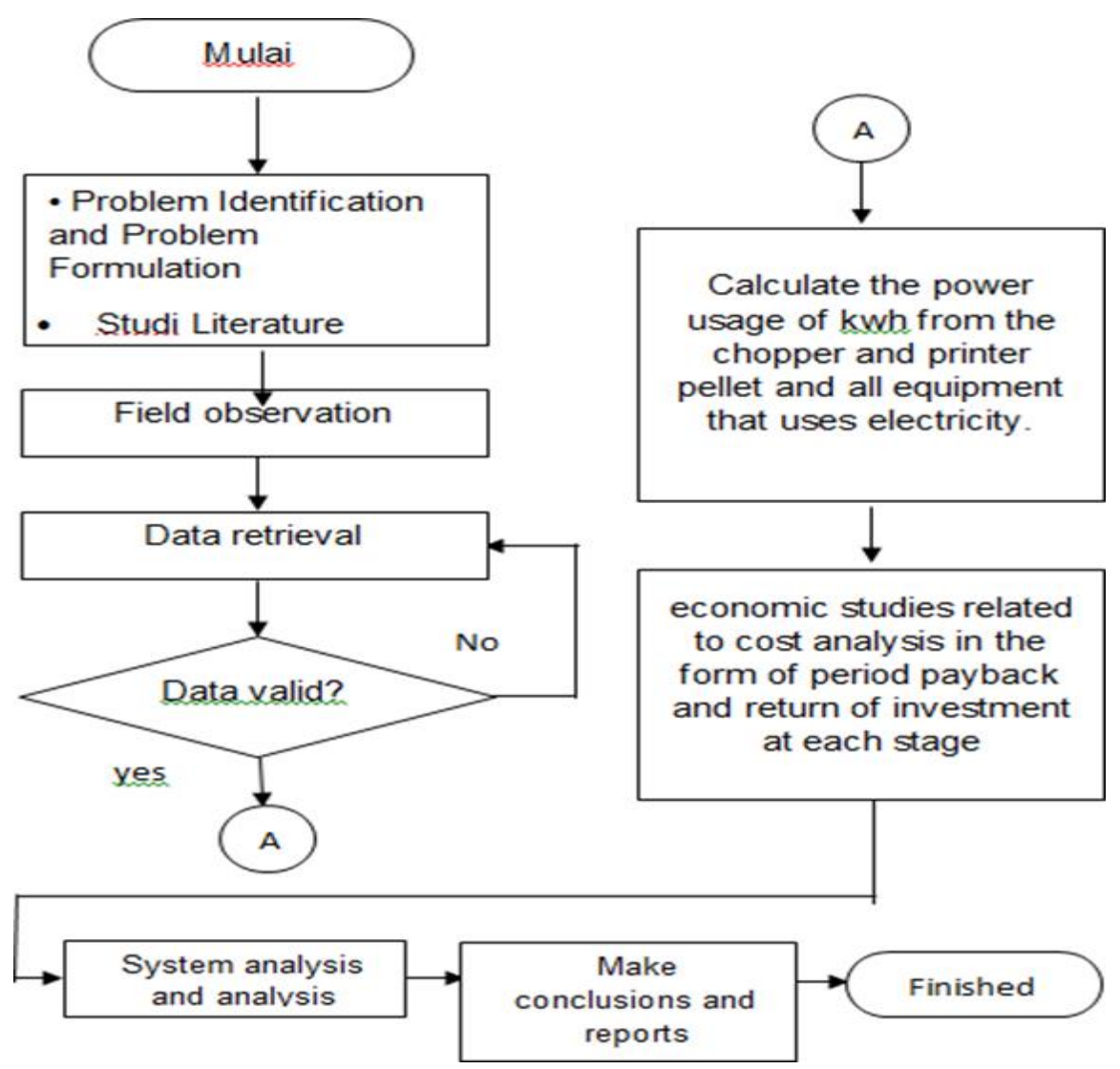

Figure 2. Research Framework

\section{RESULTS AND DISCUSSION}

Calculation of the cost of production of Local Waste Management Sites (TOSS) in the Electricity STT-PLN Jakarta Calculation of the cost of production of TOSS in STT-PLN Jakarta is done by means of calculation of waste production obtained every day. Based on the potential waste, a calculation will be carried out on how much the main equipment needs such as bamboo baskets, bioactivators, chopping machines and pellet machines needed at STT-PLN Jakarta. Assuming 1 person produces $0.7 \mathrm{~kg}$ of waste per day, with $50 \%$ of the volume dumped on campus $0,35 \mathrm{~kg}$ number of students 5000 with probability student attendant $50 \%$ then : Potential rubbish contained in STT-PLN Jakarta is:

1 person can produce $0.70 \mathrm{~kg}$ of waste per day $50 \%$ x $0.70 \mathrm{~kg}=0.35 \mathrm{~kg}$

The average number of people per day is 2500 people $0.35 \times 2500=875 \mathrm{~kg}$

The main equipment needs of TOSS at STT-PLN Jakarta:

Bamboo basket with a size $(2 \times 1 \times 1) \mathrm{m}$ can accommodate $1000 \mathrm{~kg}$ of fresh trash in STT- 
PLN Jakarta. The need for bamboo baskets with the appropriate amount of waste production per day. Through the process of peyeyeumization, the waste is ready to be chopped after a minimum of 7 days. So to get waste that is ready to be chopped every day the right cycle must be carried out and men

\section{Bioactivator}

Bioactivator is a liquid with aerobic bacteria, which is used as a tool to speed up the drying of rubbish, and eliminate the foul odor found in waste. In the process of bioactivator lubrication will work naturally in a bamboo basket with temperatures between $40-70{ }^{\circ} \mathrm{C}$. Every 1 ton of waste requires 1 liter of bioactivator. This is because the bioactivator watering process is done by adding water first with a ratio of 1 liter bioactivator: 50 liter water.

\section{Chopping Machine}

The chopping machine is an advanced process after the garbage has been peeyeumisated and then fed into the chopping machine. The need for a chopping machine unit is adjusted to the waste generated from the peeling process. In the process of peememization and sorting, a weight reduction of up to $50 \%$ of fresh waste that comes a day after 7 days will be obtained

\section{Pellet Machine}

Pellet machine is the final process in making pellets. Pellet machine unit needs are adjusted to the waste generated from the chopping process. After the choppingprocess, the chopped results are formed using a pellet machine.

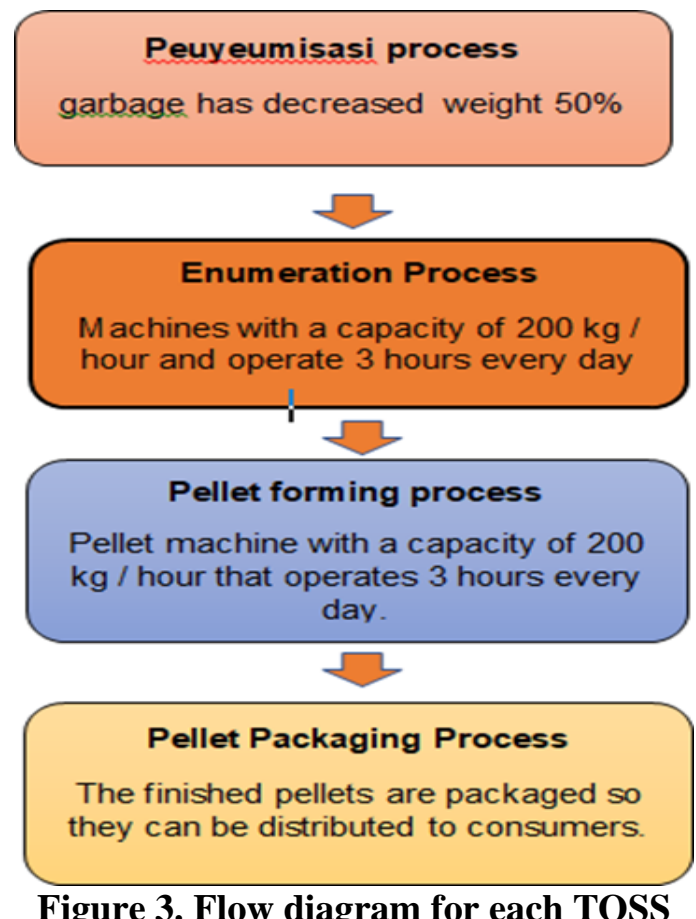

\section{Total Income}

\section{Pellet Production Results}

The results of the production of existing pellets are produced as much $437.5 \mathrm{kgx} \mathrm{Rp}$ $600,-=\operatorname{Rp} 262.500,00,-$ 


\section{Proceeds from sale of plastic waste that has economic value}

Based on the results of field observations the results obtained from the sale of waste that has economic value that sales of waste per day can reach Rp 100,000.

\section{Reducing waste transportation costs from TPS to TPA and tipping fees}

One time transportation of waste from TPS to TPA and tipping fee costs Rp.4,000,000.00 for one week according to the observation that there is one transportation during the week.

\section{STT-PLN Jakarta Economic Technical Analysis Initial Investment}

Initial investment is all costs that must be spent for development.

Table 1. Initial Investment Volume \& Job Costs

\begin{tabular}{|c|c|c|}
\hline \multicolumn{3}{|c|}{ Initial Investment } \\
\hline No & Item & Total \\
\hline 1 & civil development work+installation & Rp. $200,000,000$ \\
\hline 2 & mechanical and electrical equipment & Rp. $108,000,000$ \\
\hline 3 & Bamboo Box & Rp. $\quad 6,000,000$ \\
\hline 4 & etc & Rp. $\quad 2,000,000$ \\
\hline & Total & Rp. $316,000,000$ \\
\hline & PPN $10 \%$ & Rp. $31,600,000$ \\
\hline & Total + PPN & Rp $\quad 347,600,000$ \\
\hline
\end{tabular}

In table 1, the total budget (initial investment) for the TOSS construction by the Jakarta Electricity Electricity Unit (STT) PLN is obtained Rp 347,000,000,00,-.

\section{Expenditures / Operational Costs}

The data in table 2 is a financing table that was designed through observation and evaluation in the field.

Table 2. Operating Costs

\begin{tabular}{clccc}
\hline \multicolumn{5}{c}{ Operational } \\
\hline N0 & \multicolumn{1}{c}{ Info } & Cost/Month (Rp) & Cost/Year (Rp) & Year 1 \\
\hline 1 & Bioactivator & Rp . 520,000 & Rp. 6,240,000 & Rp .6,240,000 \\
\hline 2 & $\begin{array}{l}\text { Operator } \\
\text { Salary }\end{array}$ & Rp . 11,822,919 & Rp .141,875,028 & Rp. 141,875,028 \\
\hline 3 & Electricity cost & Rp. 5,035,705 & Rp. 60,428,460 & Rp. 60,428,460 \\
\hline 4 & over head etc. & Rp. 200,000 & Rp. 2,400,000 & Rp. 2,400,000 \\
\hline Total Expenditure & Rp. 17,578,624 & Rp. 210,943,488 & Rp. 210,943,488 \\
\hline
\end{tabular}

\section{Feasibility study}

\section{Net Present Value}

The Net Present Value (NPV) technique is calculated using the following formula:

$$
N P V=\sum_{t=0}^{n} \frac{C I F t}{(1+k)^{t}}-C O F
$$

The table shows that the total present value of net cash flows is the result of the multiplication of net cash flows with a discount factor $\left(\sum_{t}^{n} \frac{C I F_{t}}{(1+k)^{t}}-C O F\right)$ is equal to Rp801.607.469,00,- So at that cost (initial investment) Rp347.600.000,00,- then the value of NPV is:

$$
\begin{aligned}
\text { NPV } & =\operatorname{Rp} 801.607 .469,00,--\mathrm{Rp} 347.600 .000,00,- \\
& =\operatorname{Rp} 454,007,469,00,-
\end{aligned}
$$

The NPV calculation results are valued at Rp454,007,469,- (>0). 


\section{Internal Rate of Return}

Internal Rate of Return is the interest rate where the gross profit of a TOSS is equal to the present value of the project cost or the net present NPV is zero.

From the results of the excel calculation obtained that IRR> $10 \%$ (interest rate), then TOSS is feasible to proceed with IRR $=26,855 \%$

\section{Payback Period}

Payback period analysis is used to find out how long the investment reached the breakeven point or break event point which means that cash inflows are the same as cash outflows. Payback period analysis results can be seen in the appendix.

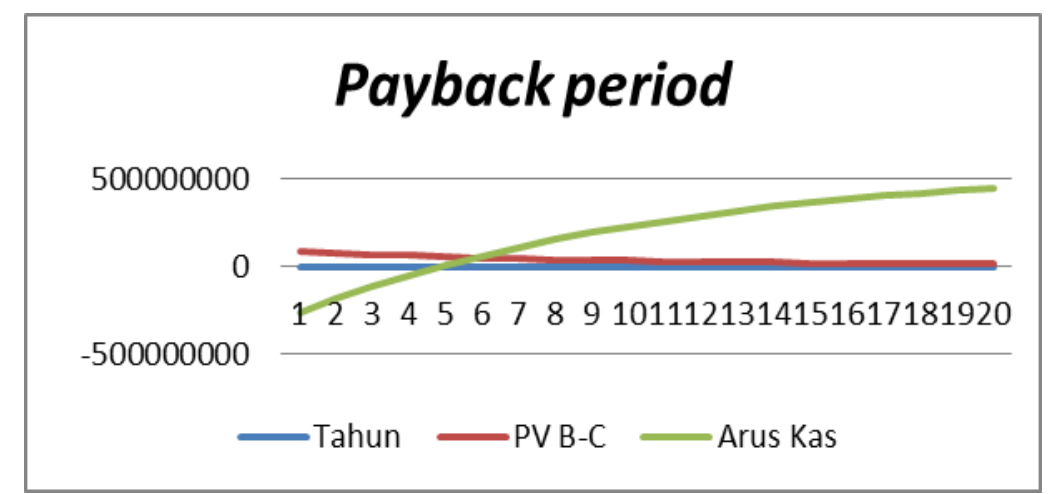

Figure 1. Graph PBP

It can be seen in the PBP chart above, where the Jakarta Electricity STT-PLN Electricity will return after the year of operation.

\section{Impact Analysis on the environment}

In the analysis of the impact on the environment, the environment around Jakarta's STT-PLN becomes cleaner. STT-PLN Jakarta People's Electricity can process its own waste into fuel.

\section{Potential Power That Can Be Generated}

Based on the results of surveys and experiments that have been carried out in Gunaksa Village, Klungkung Regency, it can be analyzed the potential power generated:

The amount of energy that can be produced: $10 \mathrm{Kg} / \mathrm{hour}=28 \mathrm{kWh}$

$$
\begin{aligned}
& 1 \mathrm{~kg}=2,8 \mathrm{~kW} \\
& 1 \mathrm{~kg}=1,19 \mathrm{kWh}
\end{aligned}
$$

Heat value of waste in STT-PLN: $3000 \mathrm{kkal} / \mathrm{Kg} \pm 300$

\section{CONCLUSIONS}

Conclusions obtained based on the results of Comparative Analysis of Energy Productivity Used to Manage Waste With Comparison of Pellet Output on Popular Electricity at STT-PLN Jakarta that the Electrical Energy used by the engine is $22 \mathrm{~kW} \times 3$ hours of operation $=66 \mathrm{kWh} \times 2$ machines $=132 \mathrm{kWh} /$ days $\times 26$ days $=3,432 \mathrm{kWh} /$ month $\times 12$ months $=41,184 \mathrm{kWh} /$ year. Investment costs are Rp347,600,000.00. Annual production costs are IDR 210,943,488 and annual benefits are IDR 305,100,000.00. profits are obtained because there is a reduction in the cost of tipping fees, transportation costs from TPS to landfill, income from the sale of pellets, sales of plastic waste. Cost of income is greater than the solid waste. Productivity, profitability with cash flow analysis on Electricity Electricity at STT-PLN Jakarta obtained NPV value > 0 which is Rp 454,007,469, and IRR > interest rate 
$(12 \%)$ that is $26,855 \%$ and Payback Period (PBP) Electricity Electricity STT- PLN Jakarta in 4.84 years. By applying the TOSS method to populist electricity at STT-PLN Jakarta and the economic analysis, the STT-PLN Jakarta Electricity Power is declared feasible. Having an advantage in quantitative (economic) terms of saving tipping fees, transportation costs from TPS to TPA, income from pellet sales, plastic waste sales. And also has a qualitative side in making the environment clean.

The suggestion is to manage waste into pellets that are consistent as the main fuel for Community Electricity, so that routine operations are needed as a populist of the Electricity Pilot Project in order to carry out social improvement to achieve the optimum level of the system. And carried out routine maintenance. It is better to collect garbage from around Jakarta STT-PLN so that income from waste production is greater and the environment is clean.

\section{REFERENCE}

Budiman, A., (2015), Biomasa Anugerah dan Berkah yang Belum Terjamah.

Krishna Purnawan Candra, Ekonomi Teknik Kuliah Ke-9 Net Present Value (NPV) Dan Kriteria Investasi Lain.

Kementerian Energi dan Sumber Daya Mineral Republik Indonesa, Direktorat Jenderal Energi Baru, Terbarukan dan Koservasi Energi. Buku Panduan Sampah Menjadi Energi (2015).

Kementerian Sumber Daya Energi dan Mineral, (2015). Program Strategis EBTK dan Kelistrikan, Jurnal energi vol. 2. November 2015.

Kholiq, Imam (2015). Pemanfaatan Energi Alternatif Sebagai Energi Baru Terbarukan Untuk Mendukung Substitusi BBM.

Legino, Supriadi. (2016), Inisiatif Listrik Kerakyatan. Solusi masalah sampah perkotaan.Solusi pasokan listrik daerah terpencil.

Median Hardianto Sirait. (2018). Perancangan Pembangkit Listrik Tenaga Sampah (PLTSa) $510 \mathrm{Kw}$ Dengan Menerapkan Tempat Olah Sampah Setempat (TOSS) Pada Setiap Desa Di Kecamatan Klungkung, Bali. Skripsi, Jurusan Teknik Elektro Sekolah Tinggi Teknik-PLN Jakarta.

Murni Rahayu Purwaningsih, 2012, Analisis Biaya Manfaat Sosial Keberadaan Pembangkit Listrik Tenaga Sampah Gedebage Bagi Masyarakat Sekitar, Badan Perencanaan Pembangunan Nasional (Bappenas) Jurnal Perencanaan Wilayah dan Kota Vol 23/No.3 Desember 2012 